\title{
ENHANCED ION YIELDS USING HIGH ENERGY WATER CLUSTER BEAMS FOR SECONDARY ION MASS SPECTROMETRY ANALYSIS AND IMAGING
}

\author{
Sadia Sheraz ${ }^{1}$, Hua Tian², John Vickerman ${ }^{4}$, Paul Blenkinsopp $^{3}$, Nicholas Winograd ${ }^{2}$ and Peter \\ Cumpson 5
}

\section{SUPPORTING INFORMATION}

\section{Experimental section}

Material and Sample Preparation. Ion yield studies were carried out on thin spin-cast films of four biorelated compounds: trehalose, a phosopholipid, 1-palmitoyl-2-oleoyl-sn-glycero-3-phosphocholine, (POPC), [Asn $\left.{ }^{1} \mathrm{Val}^{5}\right]$ angiotensin II and a cardiolipin $\left(1,1^{\prime}, 2,2^{\prime}\right.$ tetraoleoyl cardiolipin (sodium salt)). Thin films of four biomaterial standards were prepared by spin casting at 4000rpm onto silicon wafers as below,

a) D-(+)-trehalose dihydrate (Sigma Aldrich, Dorset, UK) - $12.5 \mathrm{mg}$ was dissolved in $250 \mu \mathrm{l}$ of DI H2O and $30 \mu \mathrm{l}$ was spin cast onto the substrate.

b) Angiotensin II (Cambridge Bioscience Ltd, Cambridge, UK) - 1.25 mg was dissolved in $100 \mu \mathrm{l}$ of DI $\mathrm{H} 2 \mathrm{O}$ and $30 \mu \mathrm{l}$ of this solution was spin cast.

c) 1-palmitoyl-2-oleoyl-sn-glycero-3-phosphocholine (POPC) (Sigma Aldrich, Dorset, UK) - $2.28 \mathrm{mg}$ was dissolved in $130 \mu$ l Ethanol and $30 \mu$ l was spin cast onto the substrate.

d) Cardiolipin (1,1',2,2' tetraoleoyl cardiolipin (sodium salt)) (Avanti Lipids, USA) - 0.8 mg was dissolved in $150 \mu$ l of DI H2O of which $60 \mu$ l was spincast.

e) Insulin chain B oxidised (Sigma Aldrich, US?) - $100 \mu \mathrm{g}$ of the powder was dissolved in $100 \mu \mathrm{l}$ of HPLC Grade Water and $30 \mu \mathrm{l}$ was spot on to the Si wafer and air dried.

Ion Signal investigation on standards film. As explained in the main manuscript the two aims of this research are first, to explore further the degree to which water cluster beams enhance positive and negative ion yield over that observed with argon or $\mathrm{CO}_{2}$ cluster beams and second, to explore the extent to which imaging of bio-materials benefits from the use of water cluster beams. Relevant to both these studies is the manner in which the J105 delivers ion signal. In all TOF-SIMS instruments the signal detectable that reflects the ion yield is partly determined by instrumental factors such as transmission and the mode of operation of the detector system. Unlike many TOF-SIMS systems, but analogous to most other mass spectrometers, we are using an analogue detector/measurement system such that each ion impact on the detector is amplified and the output signal may be higher than with a 
conventional single ion counting SIMS system. As in previous studies using this instrument, it is the detected secondary ion signal intensity that is reported.

After sputtering the analyte film with a sequence of primary ion exposures of $5 \times 10^{11}$ ions $\mathrm{cm}^{-2}$ to spectral steady state using a total dose of around $1 \times 10^{13}$ ions $\mathrm{cm}^{-2}$, positive ion and negative ion spectra were obtained from the four compounds using a primary ion dose of $2 \times 10^{12}$ ions $\mathrm{cm}^{-2}$ in the mass range 70 to 3000 over an area of $(300 \times 300) \mu \mathrm{m}$. The E/nucleon region below 0.3 was mainly studied and this determined the choice of beam cluster size. At Newcastle $40 \mathrm{keV}$ argon $(\mathrm{Ar})_{\mathrm{n}}$ cluster beams were used where $n$ varied from 3000 to 10000 . Water cluster beams $\left(\mathrm{H}_{2} \mathrm{O}\right)_{n}$ where $n$ varied from 8000 to 25000 . To attain the largest water cluster sizes it was necessary to provide back pressure of argon. At Penn State, $70 \mathrm{keV}\left(\mathrm{CO}_{2}\right)_{\mathrm{n}}$ cluster beams were utilized with $\mathrm{n}$ varying from 3000 to $10000.70 \mathrm{keV}\left(\mathrm{H}_{2} \mathrm{O}\right)_{\mathrm{n}}$ cluster beams with $\mathrm{n}$ in the range 13000 to 40000 were studied. Some studies of the variation of ion signal as a function of beam energy (20 to $70 \mathrm{keV}$ ) at a given cluster size were also carried out. In order to correct for any instrumental variations in comparing ion signals between experiments using the different cluster beams, all ion signals were cross-referenced to ensure internal consistency. In some cases by using the signals obtained using the $\mathrm{C}_{60}{ }^{+}$ion beam, in other cases using the argon or $\mathrm{CO}_{2}$ cluster beams.

\section{Cell and Tissue imaging - preparation and methods.}

Cell preparation. HeLa cells, an immortalized cervical cancer cell line, were incubated in DMEM media at $37{ }^{\circ} \mathrm{C}$ and with $5 \% \mathrm{CO}_{2}$ for two days. Upon the cell passage, the cells were cultured in 6-well plates with pre-cleaned Si wafers $(5 \mathrm{~mm} \times 5 \mathrm{~mm})$ submerged in the media. After $12 \mathrm{~h}$ incubation at $37^{\circ} \mathrm{C}$ and with 5 $\% \mathrm{CO}_{2}$, the $\mathrm{Si}$ wafers were collected and prepared in three ways: 1 ) Chemically fixed with $2 \%$ glutaraldehyde for $15 \mathrm{~min}$, followed by washing with $0.15 \mathrm{M}$ ammonium formate solution three times and then air-dried. 2) Followed by the same chemical fixation and washing, fast-frozen into liquid ethane and then mounted onto liquid nitrogen cooled sample stub for SIMS measurement at cold stage with temperature consistent at $103 \mathrm{~K}$. 3) Washed directly with $0.15 \mathrm{M}$ ammonium formate solution three times then plunge-frozen into liquid ethane and then transferred to a sample stub immersed in liquid nitrogen. The sample stub was loaded on pre-cooled sample stage and analyzed at $103 \mathrm{~K}$.

Animal tissue preparation. The rat brain sections were provided by University of Pittsburgh. Consecutive $6 \mu \mathrm{m}$ coronal brain sections were cut at $-21{ }^{\circ} \mathrm{C}$ and placed on ITO slides. Sections were stored for less than 1 day at $-80^{\circ} \mathrm{C}$ until analysis. The frozen tissue sections were dried under vacuum at $-4{ }^{\circ} \mathrm{C}$ and then brought to room temperature for SIMS analysis. 


\section{Cell and tissue imaging}

To evaluate the application of water cluster beams to the analysis of real biological samples, a $70 \mathrm{keV}$ $\left(\mathrm{H}_{2} \mathrm{O}\right)_{29,000^{+}}$(E/nucleon 0.13) beam was compared with a $70 \mathrm{keV}\left(\mathrm{CO}_{2}\right)_{12,000}{ }^{+}$beam (also $\mathrm{E} /$ nucleon 0.13 ) to image each sample. For cells, depth profiling was performed with $128 \times 128$ pixels over an area of $128 \times 128 \mu \mathrm{m}^{2}$ using the both beams. Simultaneous sputtering and acquisition were carried out continuously with only one cluster beam until reaching a dose of $1.25 \times 10^{14}$ ions $\mathrm{cm}^{-2}$. For tissue imaging, we first analyzed a small area, Cornu Ammonis CA3 region of hippocampus on two consecutive sections using both beams respectively. The images of CA3 were acquired by one tile image over an area of $420 \times 420 \mu \mathrm{m}^{2}$ by $256 \times 256$ pixels at a dose of $1.2 \times 10^{13}$ ions $\mathrm{cm}^{-2}$ for both beams. Then $2 \times 2$ such tiles were stitched together to produce an image of the dentate gyrus (DG) region over $840 \times 840 \mu \mathrm{m}^{2}$ using solely the water beam.

\section{FIGURES}

Figure S1 Positive and negative ion spectra from (a), [Asn ${ }^{1}$ Val $\left.{ }^{5}\right]$ angiotensin II; (b) phosopholipid, 1palmitoyl-2-oleoyl-sn-glycero-3-phosphocholine, (POPC) and (c) cardiolipin (1,1',2,2' tetraoleoyl cardiolipin (sodium salt), obtained using $40 \mathrm{keV}\left(\mathrm{CO}_{2}\right)$ and $40 \mathrm{keV}\left(\mathrm{H}_{2} \mathrm{O}\right)$ cluster beams with a primary ion dose of $2 \times 10^{12}$ ions $\mathrm{cm}^{-2}$.

Figure S2 Spectra from Insulin using $40 \mathrm{keV}\left(\mathrm{CO}_{2}\right)_{6000}$ and $40 \mathrm{keV}\left(\mathrm{H}_{2} \mathrm{O}\right)_{16000}$ cluster beams with a primary ion dose of $2 \times 10^{12}$ ions $\mathrm{cm}^{-2}$.

Figure S3 The variation of positive 'molecular' secondary ion yields as a function of E/nucleon from (a) trehalose, comparing 40 and $70 \mathrm{keV}\left(\mathrm{CO}_{2}\right)_{\mathrm{n}}$ and $\left(\mathrm{H}_{2} \mathrm{O}\right)_{\mathrm{n}}$ beams with a dose of $2 \times 10^{12}$ ions $\mathrm{cm}^{-2}$; (b) [Asn ${ }^{1}$ Val ${ }^{5}$ ] angiotensin $\mathrm{II}$, comparing $40 \mathrm{keV}\left(\mathrm{ArCO}_{2}\right)_{\mathrm{n}}$ and $\left(\mathrm{H}_{2} \mathrm{O}\right)_{\mathrm{n}}$ beams with an ion dose of $2 \times 10^{12}$ ions $\mathrm{cm}^{-2}$; (c) POPC comparing $40 \mathrm{keV}\left(\mathrm{ArCO}_{2}\right)_{\mathrm{n}}$ and $\left(\mathrm{H}_{2} \mathrm{O}\right)_{\mathrm{n}}$ beams with an ion dose of $2 \times 10^{12}$ ions $\mathrm{cm}^{-2}$ and (d) $1,1^{\prime}, 2,2^{\prime}$ tetraoleoyl cardiolipin (sodium salt) comparing $40 \mathrm{keV}\left(\mathrm{ArCO}_{2}\right)_{n}$ and $\left(\mathrm{H}_{2} \mathrm{O}\right)_{n}$ beams with an ion dose of $5 \times 10^{11}$ ions $\mathrm{cm}^{-2}$.

Figure S4 SI Yields of $[\mathrm{M}+\mathrm{H}],[\mathrm{M}-\mathrm{OH}]$ and $[\mathrm{M}-\mathrm{H}]$ for trehalose, at $\sim \mathrm{E} / \mathrm{n} 3 \mathrm{eV}(\mathrm{E} /$ nucleon $~ 0.16)$, plotted relative to $70 \mathrm{keV}\left(\mathrm{H}_{2} \mathrm{O}\right)_{24000}$.

Figure S5 Negative ion spectra from HeLa cells using $\left(\mathrm{CO}_{2}\right)_{13.9 \mathrm{k}}$ and $70 \mathrm{keV}\left(\mathrm{H}_{2} \mathrm{O}\right)_{29 \mathrm{k}}$ on $\mathrm{GA}$ fixed cells at RT in (a) and (d), on GA fixed at $100 \mathrm{~K}$ in (b) and (e) and on cryofixed cells at $100 \mathrm{~K}$ in (c) and (f) respectively. 
Figure S6 Depth profiling of HeLa cells using $70 \mathrm{keV}\left(\mathrm{H}_{2} \mathrm{O}\right)_{28 \mathrm{k}}{ }^{+}$in Panel A and $70 \mathrm{keV}\left(\mathrm{CO}_{2}\right)_{12 \mathrm{k}}{ }^{+}$in Panel B. The sequence of images were acquired with $128 \times 128$ pixel over $128 \times 128 \mu \mathrm{m}^{2}$ with an ion dose of 9.3 $\times 10^{12}$ ions $/ \mathrm{cm}^{2}$ using $\mathrm{H}_{2} \mathrm{O}$ cluster beam and $1.9 \times 10^{13}$ ions $\mathrm{cm}^{-2}$ using $\mathrm{CO}_{2}$ cluster beam for each layer. $\mathrm{L} 1$ denotes layer 1, L5 layer 5, etc. The total negative ion images are shown as grey scale image. The colour overlay images show the distribution of different biospecies. Green: PG (34:1), PS(36:1) and PI(38:4) at $\mathrm{m} / \mathrm{z}$ 747.50, 788.50 and 885.52. Magenta: cardiolipins $\mathrm{CL}(68: 2), \mathrm{CL}(70: 3), \mathrm{CL}(72: 11)$ and $\mathrm{CL}(72: 4)$ at $\mathrm{m} / \mathrm{z}$ 1403.99, 1430.02, 1441.93 and 1456.03. Blue: Phosphate-sugar back bone at $m / z$ 195.02.

Figure S7 Movie -depth profile of a HeLa cell

Table S1 Intact lipid ion yields from the analysis of CA3 region rat brain using $70 \mathrm{keV}\left(\mathrm{H}_{2} \mathrm{O}\right)_{34 \mathrm{k}^{+}}$ compared to $70 \mathrm{keV}\left(\mathrm{CO}_{2}\right)_{13.9 \mathrm{k}^{+}}$. 
Figure S1 a) Angiotensin - positive ion
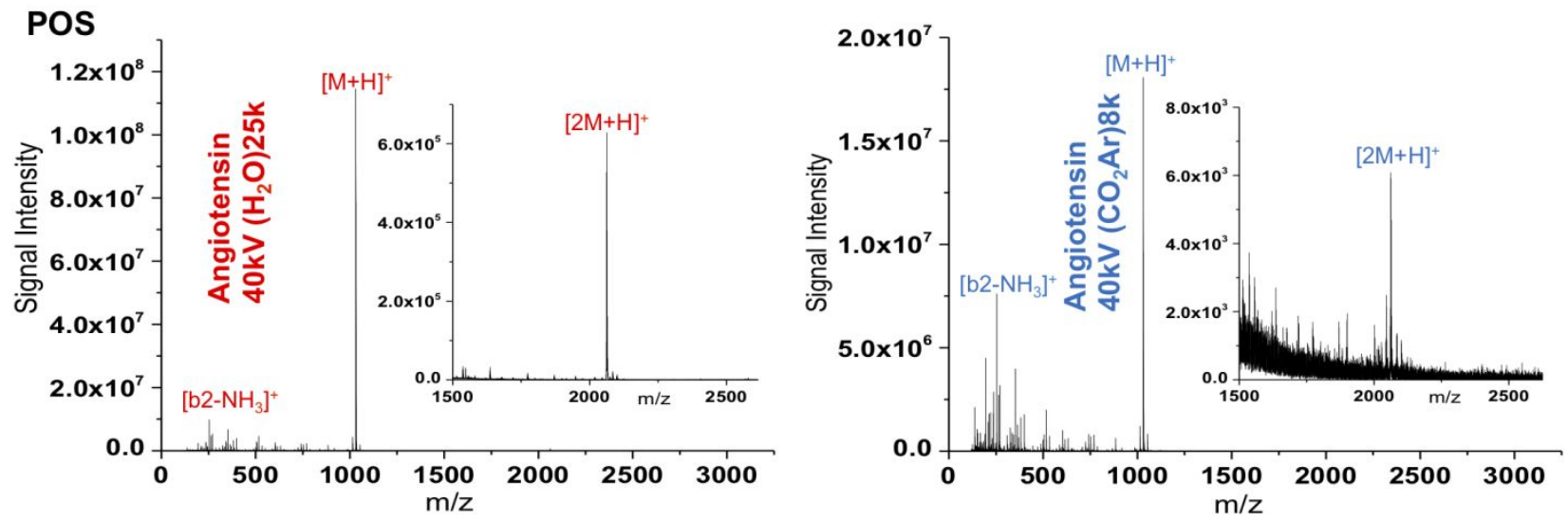

Figure S1 a) Angiotensin - negative ion
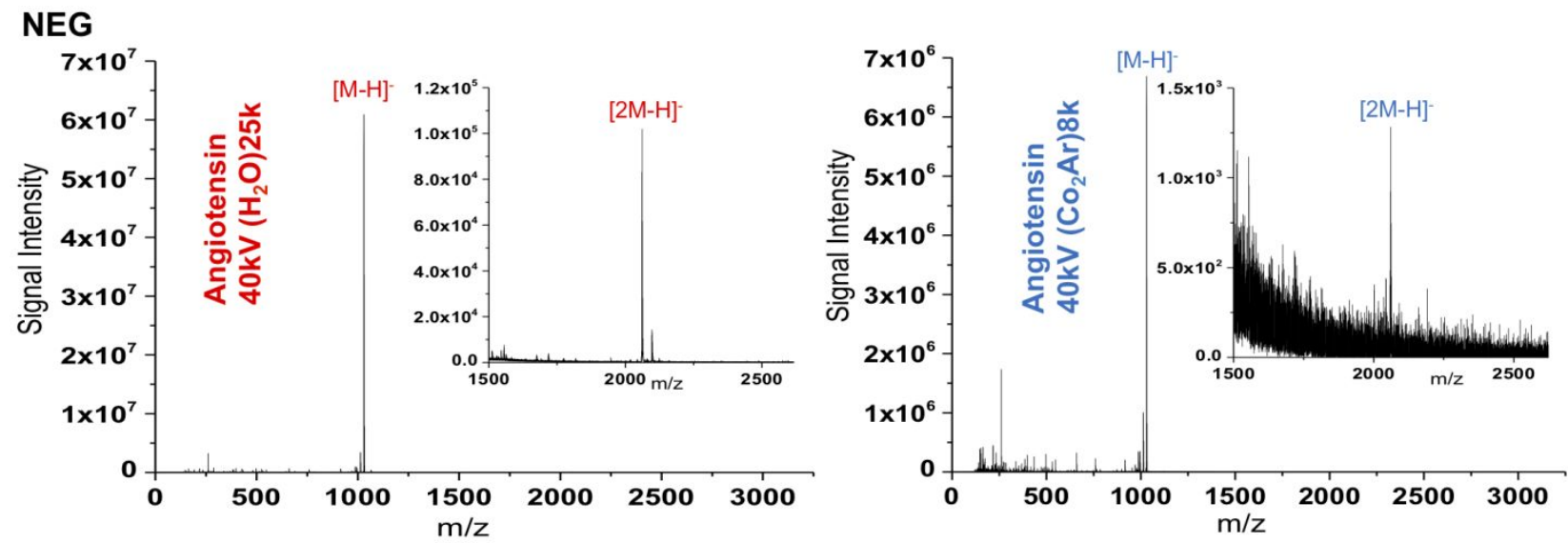

Figure S1 b) POPC positive ion
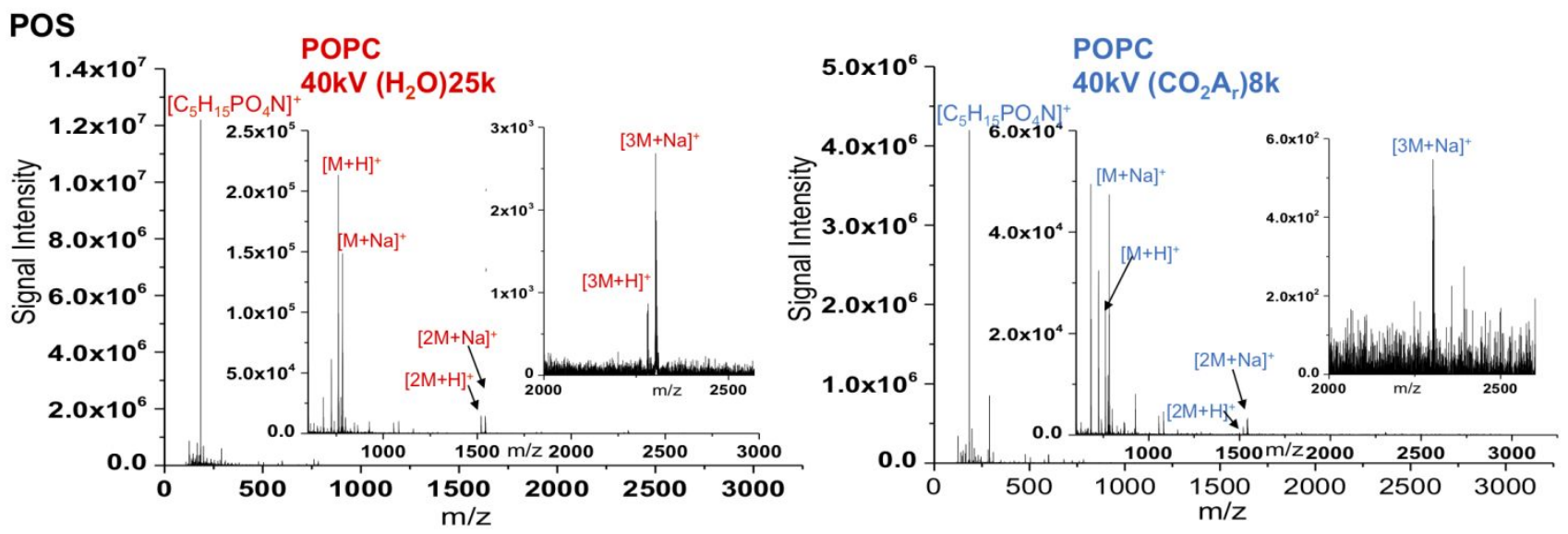

Figure S1 b) POPC negative ion
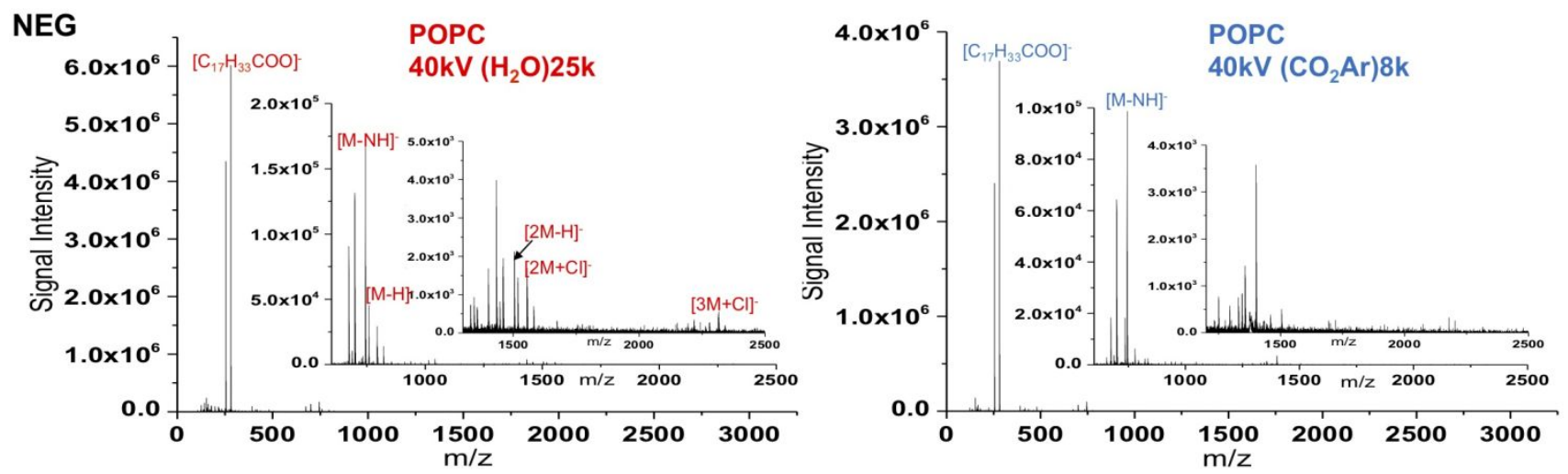
Figure S1 c) Cardiolipin - positive ion
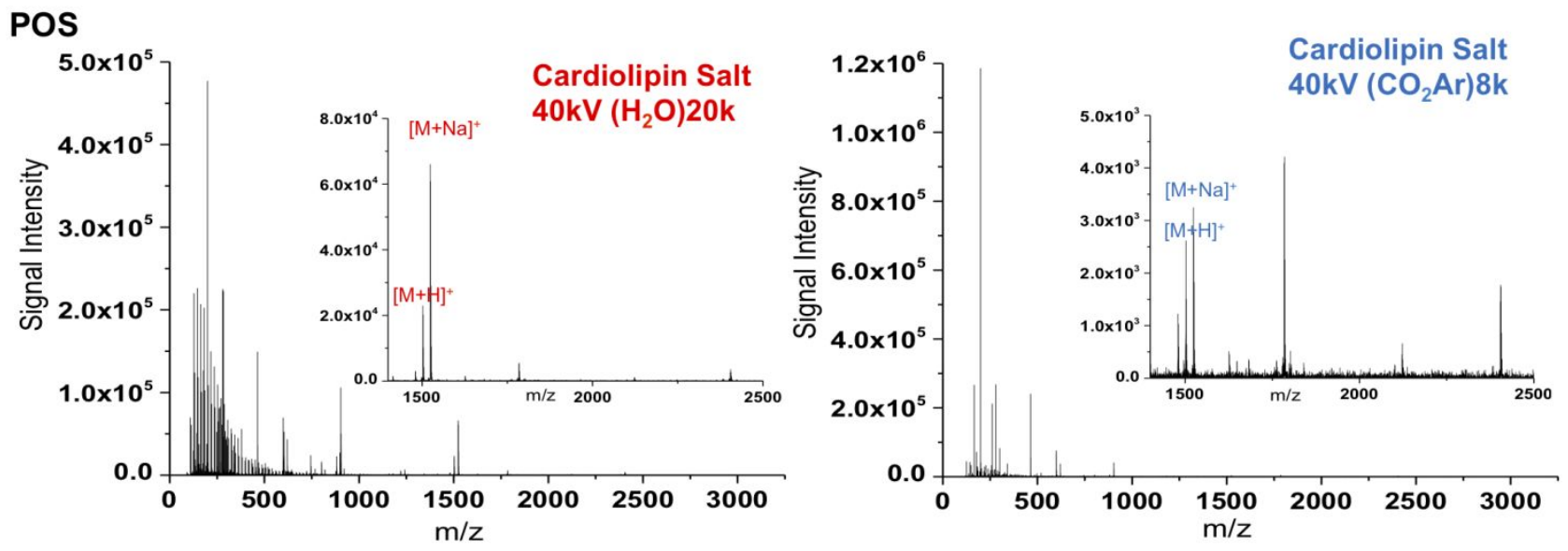

Figure S1 c) Cardiolipin - negative ion
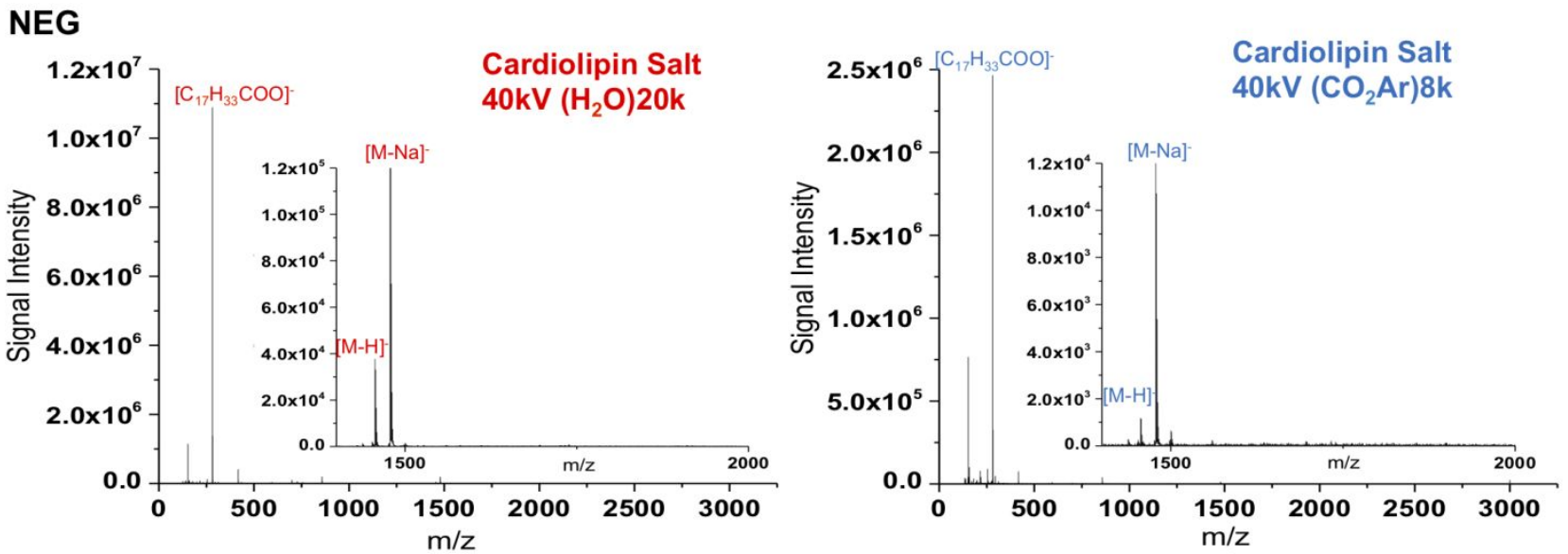

S1 Positive and negative ion spectra from (a), [Asn ${ }^{1}$ Val $\left.{ }^{5}\right]$ angiotensin II; (b) phosopholipid, 1-palmitoyl-2oleoyl-sn-glycero-3-phosphocholine, (POPC) and (c) cardiolipin $\left(1,1^{\prime}, 2,2^{\prime}\right.$ tetraoleoyl cardiolipin (sodium salt), obtained using $40 \mathrm{keV}\left(\mathrm{CO}_{2}\right)$ and $40 \mathrm{keV}\left(\mathrm{H}_{2} \mathrm{O}\right)$ cluster beams with a primary ion dose of $2 \times 10^{12}$ ions $\mathrm{cm}^{-2}$.
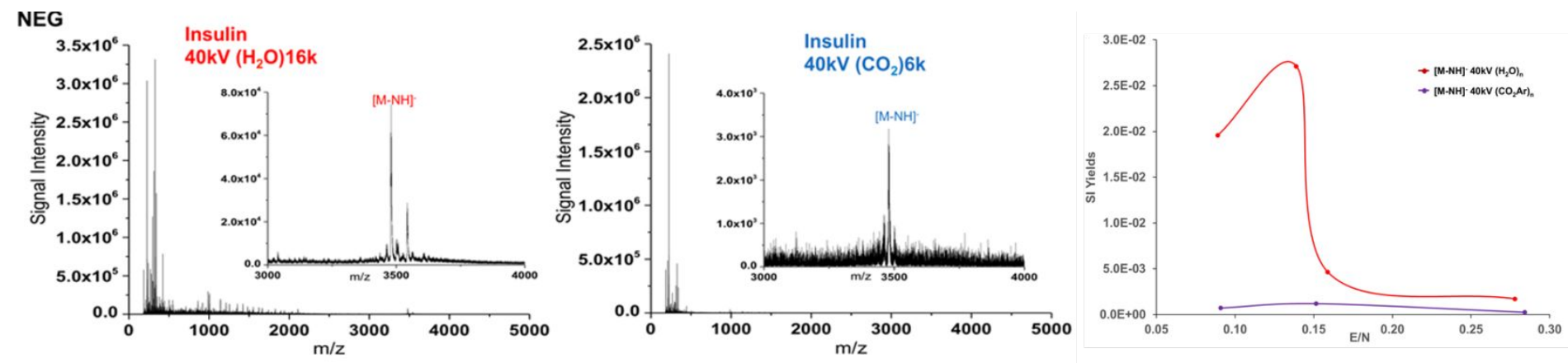

Figure S2 Negative ion Spectra from Insulin B Chain oxidised using $40 \mathrm{keV}\left(\mathrm{H}_{2} \mathrm{O}\right)_{16000}$ and $40 \mathrm{keV}$ $\left(\mathrm{CO}_{2}\right)_{6000}$ cluster beams with a primary ion dose of $2 \times 10^{12}$ ions $\mathrm{cm}^{-2}$. Below the variation of the negative insulin secondary ion yields as a function of E/nucleon. 

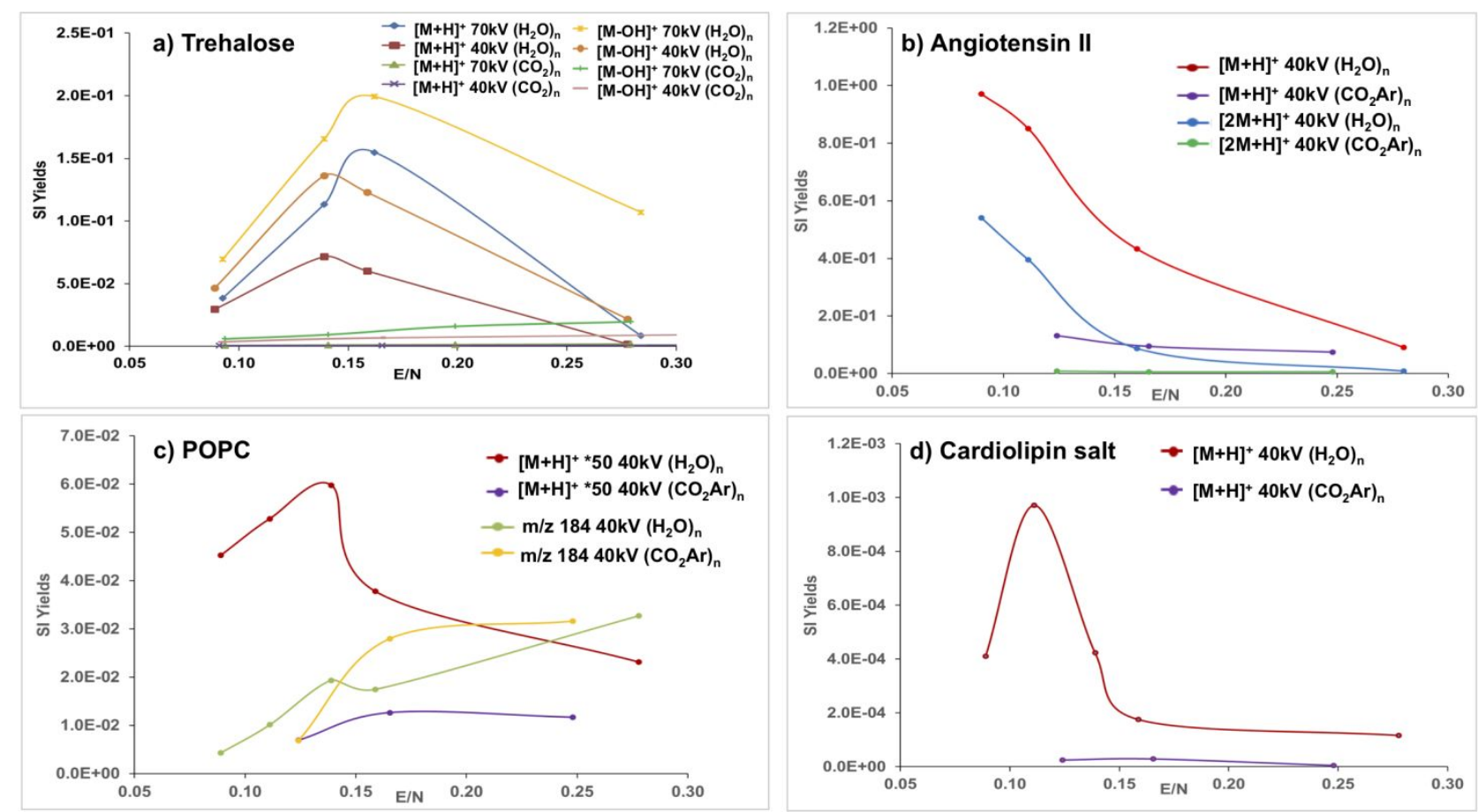

Figure S3 The variation of positive 'molecular' secondary ion yields as a function of E/nucleon from (a) trehalose, comparing 40 and $70 \mathrm{keV}\left(\mathrm{CO}_{2}\right)_{\mathrm{n}}$ and $\left(\mathrm{H}_{2} \mathrm{O}\right)_{\mathrm{n}}$ beams with a dose of $2 \times 10^{12}$ ions $\mathrm{cm}^{-2}$; (b) [Asn ${ }^{1}$ $\mathrm{Val}^{5}$ ] angiotensin $\mathrm{II}$, comparing $40 \mathrm{keV}\left(\mathrm{ArCO}_{2}\right)_{\mathrm{n}}$ and $\left(\mathrm{H}_{2} \mathrm{O}\right)_{\mathrm{n}}$ beams with an ion dose of $2 \times 10^{12}$ ions $\mathrm{cm}^{-2}$; (c) POPC comparing $40 \mathrm{keV}\left(\mathrm{ArCO}_{2}\right)_{\mathrm{n}}$ and $\left(\mathrm{H}_{2} \mathrm{O}\right)_{\mathrm{n}}$ beams with an ion dose of $2 \times 10^{12}$ ions $\mathrm{cm}^{-2}$ and (d) $1,1^{\prime}, 2,2^{\prime}$ tetraoleoyl cardiolipin (sodium salt) comparing $40 \mathrm{keV}\left(\mathrm{ArCO}_{2}\right)_{n}$ and $\left(\mathrm{H}_{2} \mathrm{O}\right)_{n}$ beams with an ion dose of $5 \times 10^{11}$ ions $\mathrm{cm}^{-2}$.

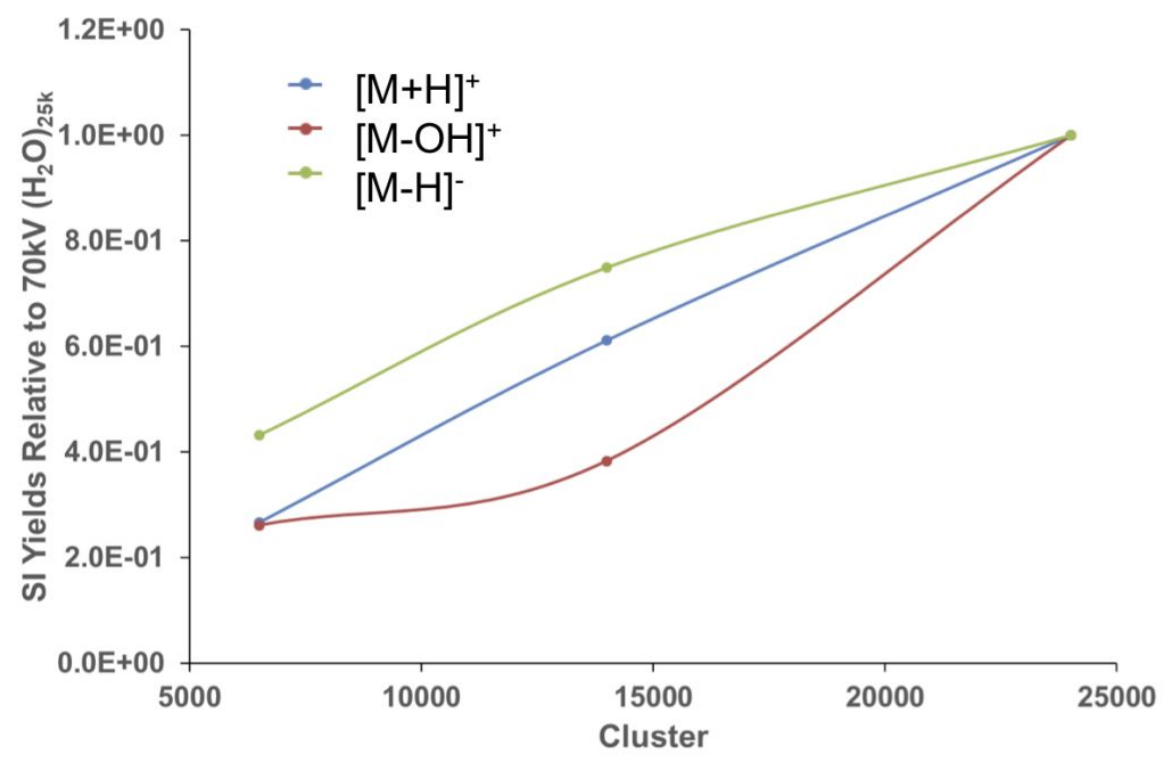

Figure S4 SI Yields of $[\mathrm{M}+\mathrm{H}],[\mathrm{M}-\mathrm{OH}]$ and $[\mathrm{M}-\mathrm{H}]$ for trehalose, at $\sim \mathrm{E} / \mathrm{n}$ 3eV $(\mathrm{E} /$ nucleon $\sim 0.16)$, plotted relative to $70 \mathrm{keV}\left(\mathrm{H}_{2} \mathrm{O}\right)_{24000}$ 


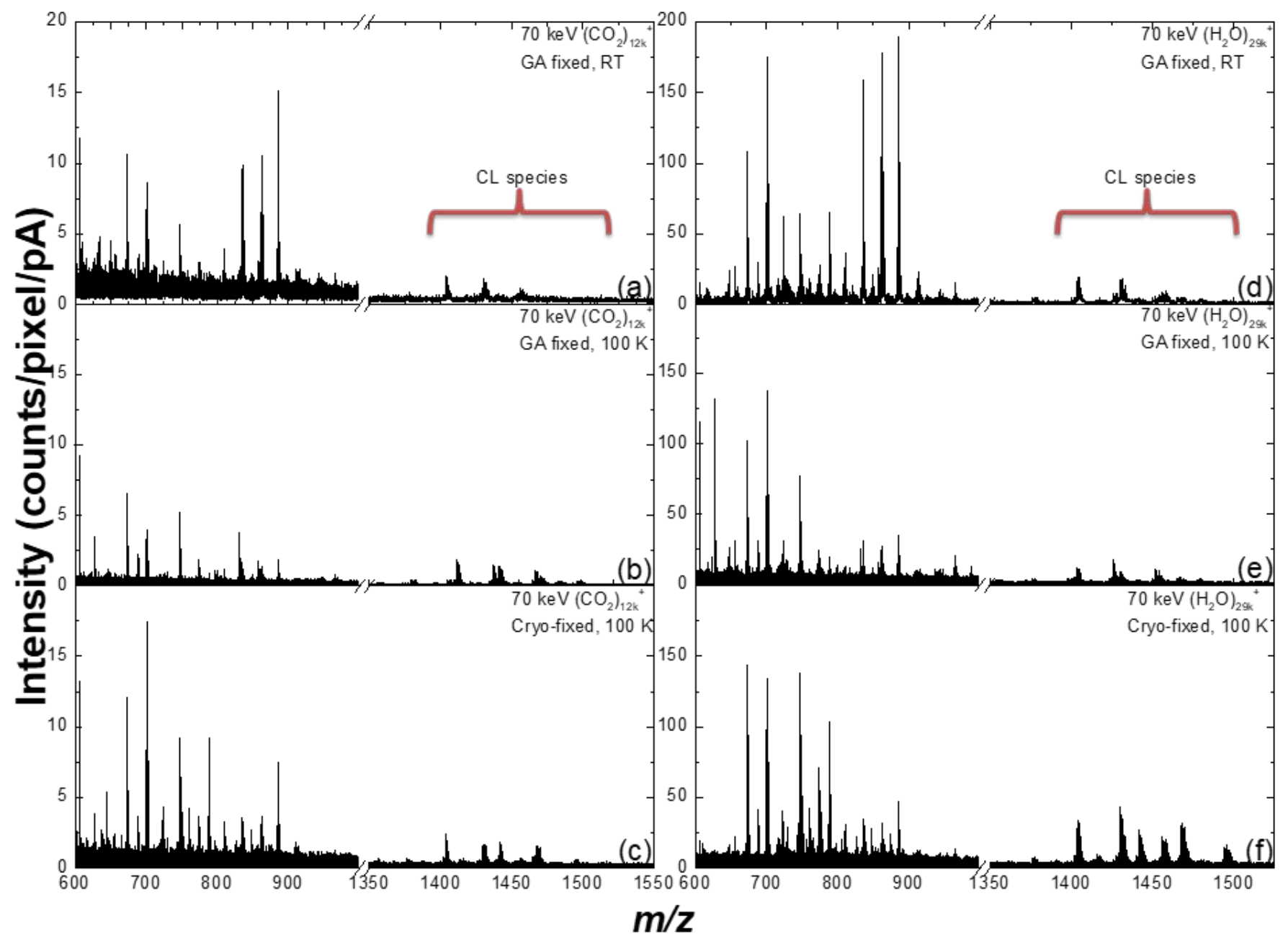

Figure S5 Negative ion spectra from HeLa cells using $\left(\mathrm{CO}_{2}\right)_{13.9 \mathrm{k}}$ and $70 \mathrm{keV}\left(\mathrm{H}_{2} \mathrm{O}\right)_{29 \mathrm{k}}$ on GA fixed cells at RT in (a) and (d), on GA fixed at $100 \mathrm{~K}$ in (b) and (e) and on cryofixed cells at $100 \mathrm{~K}$ in (c) and (f) respectively. 

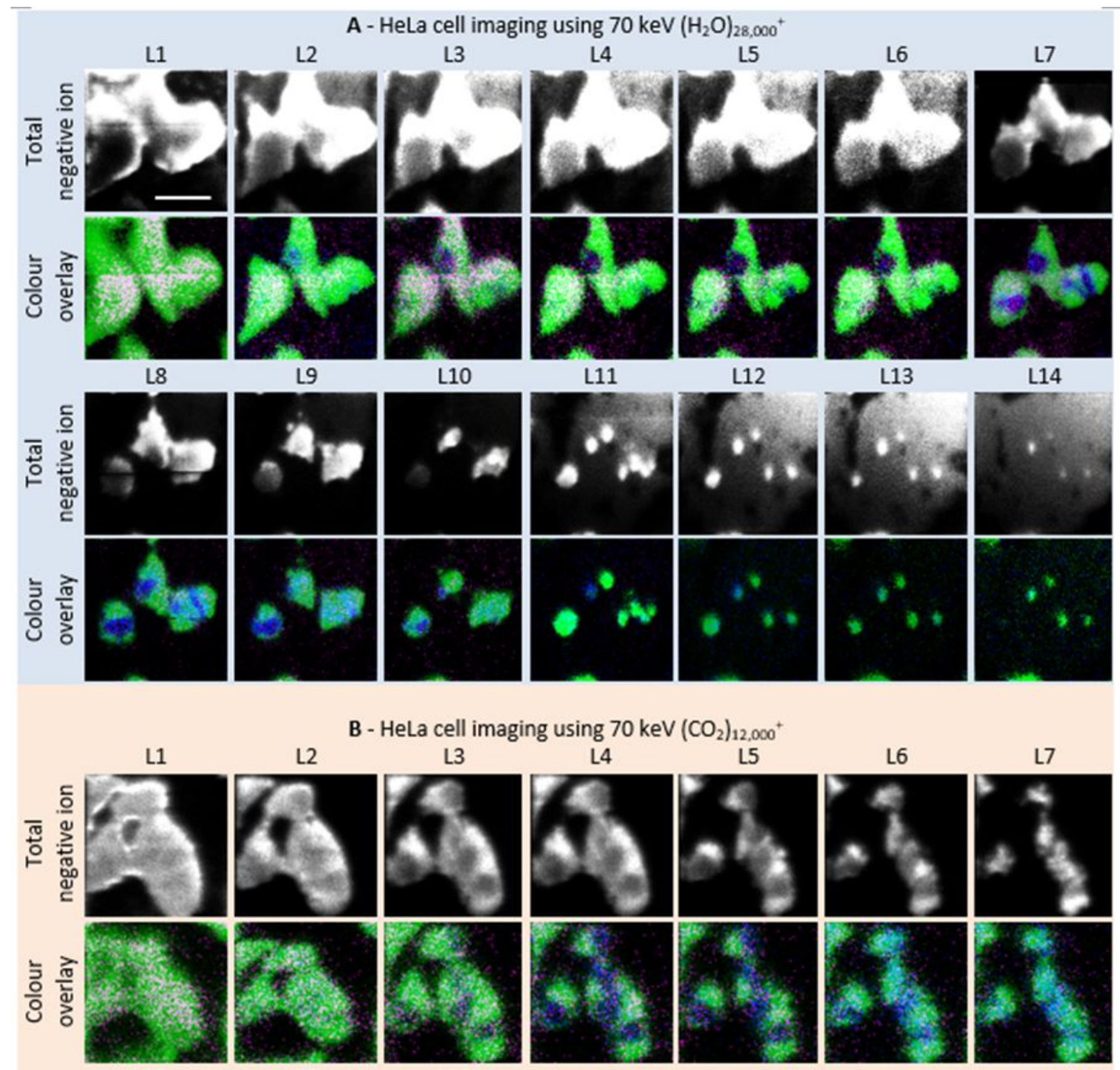

B - HeLa cell imaging using $70 \mathrm{keV}\left(\mathrm{CO}_{2}\right)_{12,000}{ }^{+}$

L2
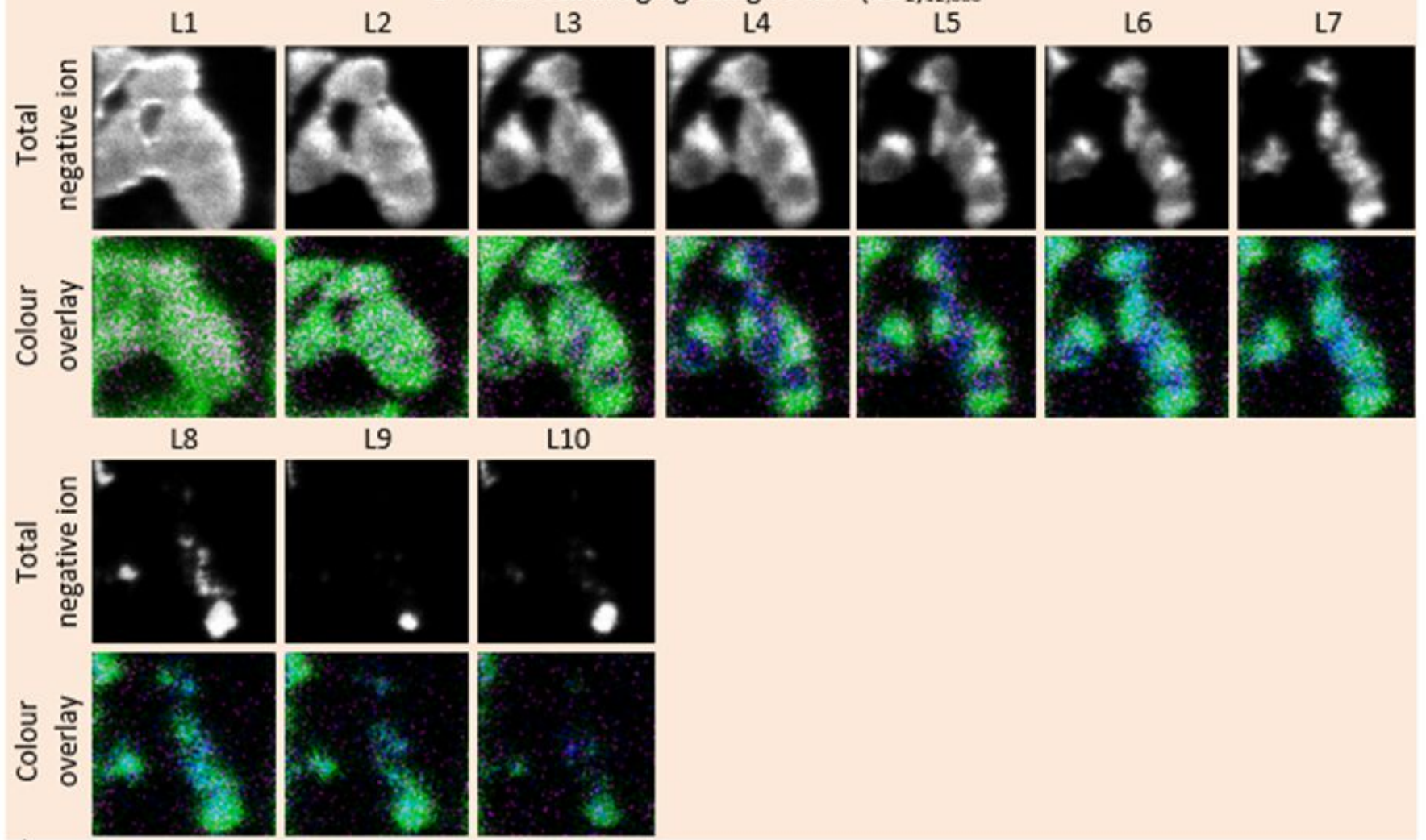

Figure S6 Depth profiling of HeLa cells using $70 \mathrm{keV}\left(\mathrm{H}_{2} \mathrm{O}\right)_{28 \mathrm{k}}{ }^{+}$in Panel A and $70 \mathrm{keV}\left(\mathrm{CO}_{2}\right)_{12 \mathrm{k}}{ }^{+}$in Panel B. The sequence of images were acquired with $128 \times 128$ pixel over $128 \times 128 \mu^{2}$ with an ion dose of 9.3 $\times 10^{12}$ ions $/ \mathrm{cm}^{2}$ using $\mathrm{H}_{2} \mathrm{O}$ cluster beam and $1.9 \times 10^{13}$ ions $\mathrm{cm}^{-2}$ using $\mathrm{CO}_{2}$ cluster beam for each layer. L1 denotes layer 1, L5 layer 5, etc. The total negative ion images are shown as grey scale image. The colour overlay images show the distribution of different biospecies. Green: PG (34:1), PS(36:1) and PI(38:4) at 
$\mathrm{m} / z$ 747.50, 788.50 and 885.52. Magenta: cardiolipins $\mathrm{CL}(68: 2), \mathrm{CL}(70: 3), \mathrm{CL}(72: 11)$ and $\mathrm{CL}(72: 4)$ at $\mathrm{m} / \mathrm{z}$ $1403.99,1430.02,1441.93$ and 1456.03. Blue: Phosphate-sugar back bone at $m / z$ 195.02.

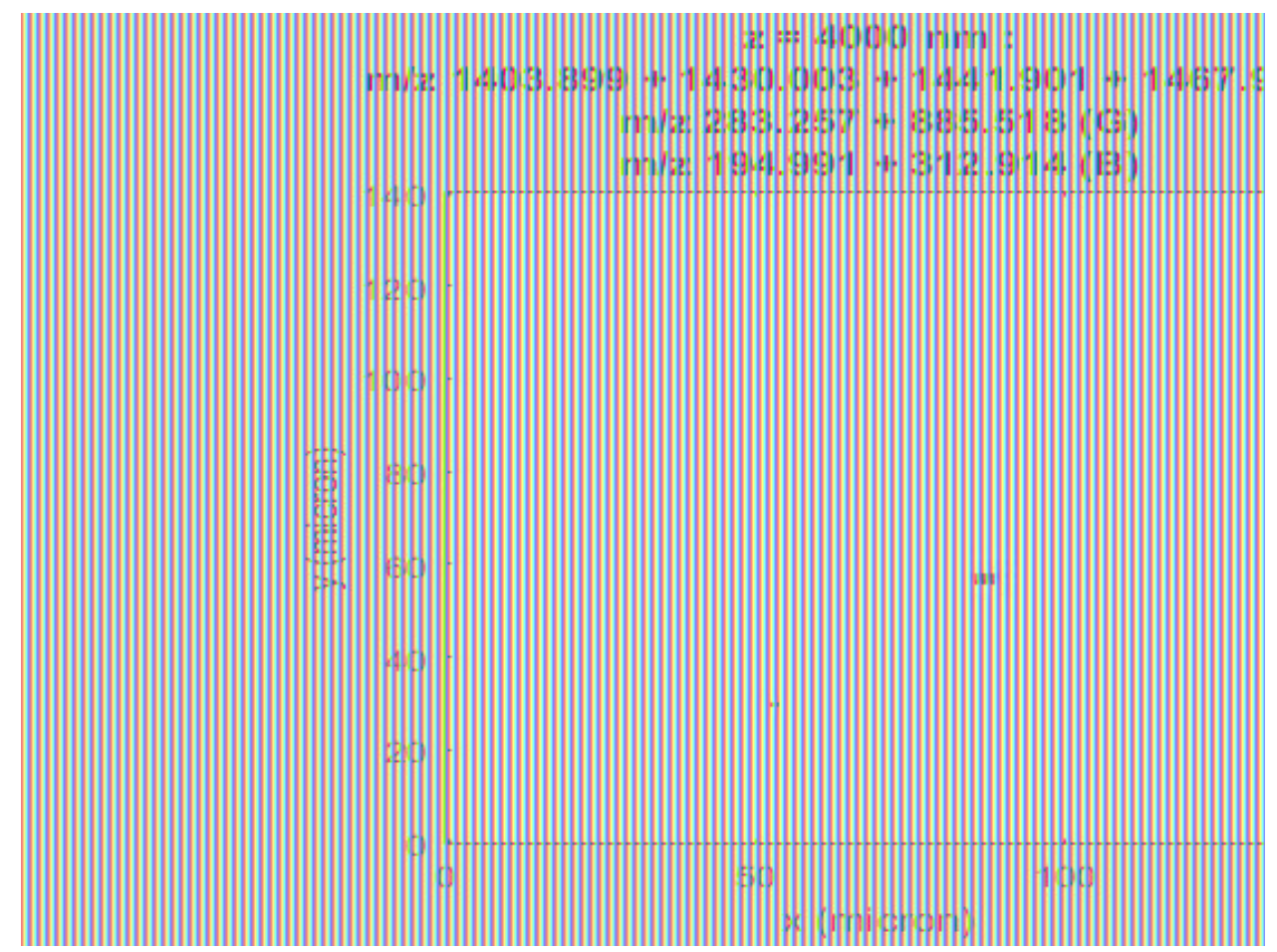

Figure S7 Reconstruction of imaging depth profile of HeLa cells using $70 \mathrm{keV}\left(\mathrm{H}_{2} \mathrm{O}\right)_{28 \mathrm{k}}{ }^{+}$. After Zcorrection, it is displayed by color overlay images of horizontal slices of cell showing the gradual reassembly of the cells. Red: cardiolipins $\mathrm{CL}(68: 2), \mathrm{CL}(70: 3), \mathrm{CL}(72: 11)$ and $\mathrm{CL}(74: 12)$ at $\mathrm{m} / \mathrm{z}$ 1403.90, 1430.00, 1441.90 and 1467.91. Green: Stearic acid and PI(38:4) at $m / z 283.26$ and 885.52. Blue: sugarphosphate backbone of nuclear acid at $m / z$ 195.00. Note: double click on the image to start the movie.

Table S1 Intact lipid ion yields from the analysis of CA3 region rat brain using $70 \mathrm{keV}\left(\mathrm{H}_{2} \mathrm{O}\right)_{34 \mathrm{k}^{+}}$ compared to $70 \mathrm{keV}\left(\mathrm{CO}_{2}\right)_{13.9 k^{+}}$.

\begin{tabular}{|c|c|c|c|c|c|c|c|}
\hline $\begin{array}{l}\text { Fatty } \\
\text { acids }\end{array}$ & $\begin{array}{c}\left(\mathrm{H}_{2} \mathrm{O}\right)_{n}^{+} / \\
\left(\mathrm{CO}_{2}\right)_{n}^{+}\end{array}$ & $\begin{array}{c}\text { Intact } \\
\text { phospho- } \\
\text { lipids }\end{array}$ & $\begin{array}{c}\left(\mathrm{H}_{2} \mathrm{O}\right)_{n}^{+} / \\
\left(\mathrm{CO}_{2}\right)_{n}^{+}\end{array}$ & cardiolipin & $\begin{array}{c}\left(\mathrm{H}_{2} \mathrm{O}\right)_{n}^{+} / \\
\left(\mathrm{CO}_{2}\right)_{n}^{+}\end{array}$ & ganglioside & $\begin{array}{c}\left(\mathrm{H}_{2} \mathrm{O}\right)_{n}^{+} / \\
\left(\mathrm{CO}_{2}\right)_{n}^{+}\end{array}$ \\
\hline 283.24 & 2.69 & 857.56 & 0.36 & 1526.04 & 12.53 & 1544.86 & 4.91 \\
\hline 281.22 & 3.68 & 906.63 & 1.17 & 1528.04 & 12.24 & 1857.92 & 7.96 \\
\hline 255.21 & 3.22 & 917.60 & 5.89 & 1500.04 & 12.62 & 1872.91 & 10.58 \\
\hline 279.22 & 4.83 & 885.56 & 2.61 & 1478.04 & 7.73 & 1901.92 & 13.68 \\
\hline \multirow[t]{7}{*}{419.23} & 2.14 & 879.56 & 1.21 & 1476.00 & 7.94 & 2187.91 & 15.71 \\
\hline & & 873.52 & 6.94 & 1449.98 & 5.56 & 2203.89 & 14.44 \\
\hline & & 835.54 & 8.19 & & & & \\
\hline & & 851.56 & 2.19 & & & & \\
\hline & & 849.60 & 6.07 & & & & \\
\hline & & 823.61 & 1.93 & & & & \\
\hline & & 807.58 & 1.23 & & & & \\
\hline
\end{tabular}




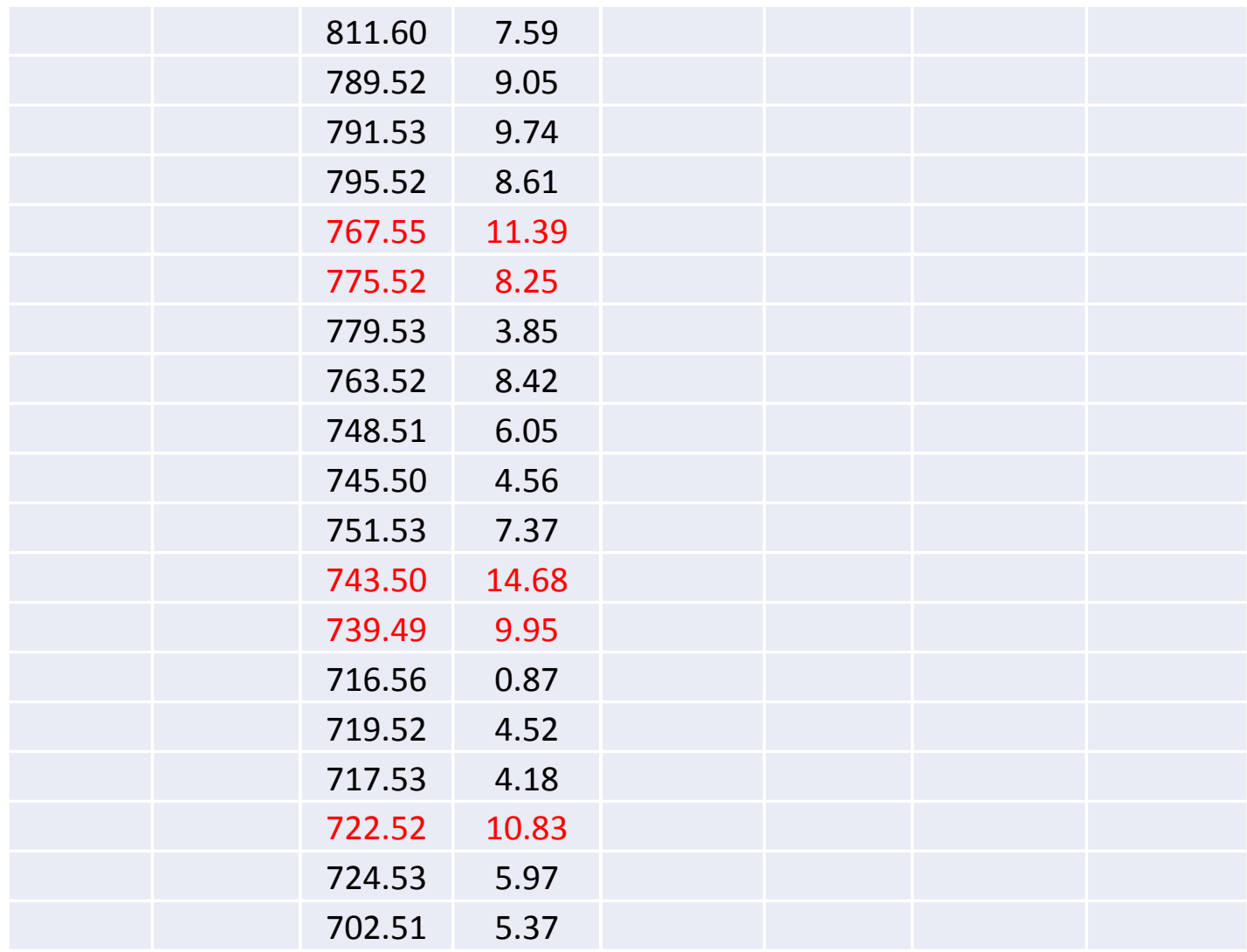

